\title{
Cyclic Relective Model for Promoting Prospective English Teachers' Creativity in Instructional Designing
}

\author{
Luh Putu Artini* \\ English Education Department \\ Universitas Pendidikan Ganesha \\ Bali, Indonesia \\ *putu.artini@undiksha.ac.id
}

\author{
Ni Nyoman Padmadewi \\ English Education Department \\ Universitas Pendidikan Ganesha \\ Bali, Indonesia \\ nym.padmadewi@undiksha.ac.id
}

\begin{abstract}
Educational research so far has been scattered around the efforts to optimize students' academic achievement rather than real life literacy skills. To anticipate this, the effort for insertion of the 21 st century skills has been underway. Studies found that one of the obstacles for satisfactory results of the effort was to do with the lack of creativity on the part of the teacher in designing effective instruction. This paper reports the results of a classroom research that aimed at describing how cyclic reflective model (CRM) of teaching influence prospective English teachers' creativity in instructional designing. 60 second year students enrolled in Strategy and Design Course were involved in the study, 30 of which were treated using Cyclic Reflective Model (CRM) and the others went through a conventional teaching and learning process. Creativity was measured through Sternberg's 5 components of creativity comprising expertise, imaginative thinking skills, a venturesome personality, intrinsic motivation, and creative environment. This study found that prospective English teachers who systematically evaluate their own designs and refine their design accordingly were more creative in 3 of the five components and were more sensitive about hierarchical order of the operational verbs used for success indicator formulation.
\end{abstract}

Keywords: creativity, cyclic reflective model, instructional designing

\section{INTRODUCTION}

Formal education commonly aimed at two big targets: to make children to be smart (cognitive competence), and to be good (personal life skills). For this reason, school curriculum development mainly accommodates these two targets $[1,2]$. In Indonesia, which has a long history of route learning [3], the efforts to insert personal life skills into the curriculum has been found challenging. The Program for International Students Assessment (PISA) that specifically measure students' life skills in Science, Mathematics, and Reading reveals the position of Indonesian students in the 64th, 65th, and 63rd respectively out of 70 countries assessed [3]. On the other hand, many Indonesian students won in international Olympiads, especially on Science and Mathematics [4]. These indicate that Indonesian students achieved the content knowledge quite well but not much in the personal life skills.
Developing personal life skills has long been a concern in education system all over the world [5,6], because these skills are the main determinant for life success [7]. Personal life skills here refer to individuals' abilities to adapt skills and behaviors to different situations / social communities and always readily and effectively deal with any problems or challenges in life [8]. These life skills are not the skills that the children born with. As a skill, someone must have gone through a long process of building the skills through experiences and purposeful activities at schools [9]. The life skills are commonly classified into different set of domains. One of those classified the set into ten skills: self-awareness, empathy, critical thinking, creative thinking, decision making, problem solving, effective communication, interpersonal relationship, coping with stress, and coping with emotion [10]. Personal life skills may also be classified into 4 skills, known as $4 \mathrm{Cs}$, because they comprise of collaboration, creativity, critical thinking and communication [11]. These two classifications overlap in a way that the latter classification is more general and may include the other components of the previous classification.

The 4Cs are widely addressed in Indonesian school curricula and become a major reference in developing personal life skills that are blended into the daily teaching and learning practices inside the classroom. In term of collaboration, for example, students are trained to work effectively in groups, solve problems and do project in a conducive teamwork. Creative thinking skills are built through challenging tasks that require students to use their imagination and creativity. Critical thinking skills are to do with students' ability to analyze and evaluate something and use this to solve problems or to refine or create something. Last, but not least, communication skills are related to the ability to express or respond to ideas, explain, describe, and communicate to diverse interlocutors in various situations.

The skills as mentioned above has been addressed in different ways in Indonesian. They may be taught consecutively by providing special teaching materials, following special approaches, and employing special strategies for teaching. Teachers are responsible to facilitate students to understand the concepts, to model the implementation, and to 
habituate the values. Some other schools may insert the personal life skills concurrently into the lessons, or in other words, the skills are not specifically planned but rather more spontaneously according to situations. The latter was found to be the common practice in Indonesian schools so far. Teachers tend to plan the grouping in the classroom, however, the target for the grouping strategy was likely to 'go with the flow'. In other words, putting students into groups was part of the classroom management routines instead of purposefully designed for building collaborative skills of the students [12].

Inserting the $21 \mathrm{st}$ century learning skills into school curricula (i.e. collaboration or ability to work together as a team; creativity or ability to think and act in different ways and create something new; critical or ability to judge, evaluate and solve problems in an effective way; and communicative or ability to express ideas and communicate effectively; is the major concern of education reform in Indonesia. These skills are the basic personal life skills needed both for professional and social life therefore teachers are expected to be able to put these into practice in daily activities in the classroom. These require special approaches and strategies on the part of the teachers. However, research found that teachers are lack of creativity in designing effective teaching and learning that insert the 21 st century learning skills.

Creativity has been widely agreed as a capacity possessed by all individuals that make it possible for them to think in diverse ways about something. This capacity helps them solve problems effectively, and make good decisions when needed. In other words, creativity is not genetic because every individual does not have creativity since born, but rather gained from real life experiences including from formal education (i.e. school) [13]. Ones need support and facilitation to build their creativity, and for young generation who attend schools, the person in charge for the growth of creativity is the teacher.

Ideally, school should provide opportunities for learners to develop their own capacity to optimize their learning through self-directed learning [14], learning through inquiry/discovery [15]; working collaboratively to solve problems [16], working on a project [17-21], and learning by doing [22]. All these activities will strengthen their personal life skills because in addition to achieve the academic targets, the students will also build the habit or skills of the $21^{\text {st }}$ century learning. All the activities require them to be responsible toward their own learning or the center of learning. More importantly, these require the teachers to be creative in designing their lessons so that the life skills needed can be naturally inserted.

There has been a long history for route learning in Indonesian schools, in which in all schools, students should go through the same materials at the same time, because they were to be tested on the same content at the end of the school terms or years. This 'exams-oriented' learning is still practiced at present, which encouraged highly controlled activities in the classroom. The main success indicator was that the students should achieve the passing grade and perform satisfactorily in the national exams. Output (i.e. academic achievement score) becomes the main goal of schooling instead of the outcome (i.e. students' life skills for real life readiness). This can be argued as one of the reasons for the low average scores of the Indonesian students in PISA. Thus, it is not difficult to understand that the biggest challenge for education quality in Indonesia is to do with teachers' creativity.

\section{Preparing Teachers to Be Creative}

Teachers' creativity in Indonesia has become an important issue since the launching of Competence-based Curriculum in 2004. This year was considered as an important date for education reform in which education trend shifted from teacher centered learning to students centered learning. Students were no longer considered as the objects of learning but the subjects of learning because they all have all the potencies to their own capacities to develop their own learning. This curriculum was developed into School-based Curriculum in 2006 when schools were given the authority to adapt the national curriculum according to the community real needs and potencies. Finally, in 2013, the latest version of the curriculum suggests the insertion of character education and the $21^{\text {st }}$ century learning skills. So far, a considerable amount of professional development programs has been made available for teachers in order to be able to adapt to the new expectations of the new curriculum.

Most professional development programs for teachers were aimed at changing the mindset of the teachers from teachercentered learning to student-centered learning. Many researchers found that this is difficult since 'senior' teachers (who had more than 10 years of teaching experiences) tend to have been comfortable with conventional approaches that put themselves as the dominant figures in the classroom [23]. In the context where teacher centered learning has been a school culture [24], changing the teachers' mindset from teacher to student-centered is problematic.

One of the strategies to anticipate teachers' problem of creativity is through curriculum reform in teacher education institution where prospective teachers are trained. Teacher education should have a special program or course that specifically train prospective teachers to build their creativity in teaching. In English Education Department of Universitas Pendidikan Ganesha, Bali, Indonesia, the course is called Strategy and Design. This course trains the second year students (of the four-year candidacy for the degree of Bachelor of Arts in English language education) to cope with the education reform in this $21^{\text {st }}$ century learning. The three hour credit course is formatted in the form of workshops where students learn to design and create innovative lessons either in groups or individually.

The Strategy and Design Course comprises 16 times of 150 minutes regular in class activities with the presence of the trainers and other 16 times 150 minutes of working on their own or groups to plan a lesson, create the relevant teaching media and material needed. During the class activities, the prospective English teachers present their design, do a reflection, and redesign the instructions. Every project gets feedbacks from peers and trainers. 
Cyclic reflective model (hereafter, CRM) in this research is described as a model of teaching in which students have a full control over their process of learning in which they were guided by questions they have to ask and answer themselves in the attempt to optimize their own learning. In the Strategy and Design Course, they have to be able to foresee their future classroom through an instructional designing activities comprising: lesson plans, teaching materials and media. In this case, they have to be creative in a way that the lessons should meet the process standard advocated by the ministerial regulation No 22, year 2016, in which the lesson must be innovative, inspiring, challenging and fun.

CRM questions are provided for the students to answer after they finished their first, second, and final draft of the instructional design. The questions adapted from the reflective teaching cycle: (1) What happened during the preparation of your instructional design? (2) What were you thinking and feeling about your design?; (3) What was good and bad about your design?; (4) What made your instructional design good / bad?; (5) What could have you done?; and (6) What would you do in your next design?

Meanwhile, students' creativity is described through Teaching Creativity Questionnaire that was developed based on Sternberg's 5 components of creativity comprising:

- Expertise (the use of various ideas, images, phrases as mental building blocks)

- Imaginative thinking skills (the ability to see things in new ways, to recognize patterns, to make connections)

- A venturesome personality (tolerate ambiguity and risk, preserves in overcoming obstacles, seeks new experiences rather than following the pack

- Intrinsic motivation (being driven more by interest, satisfaction)

- Creative environment (sparks, supports, and refines creative ideas)

This research describes how cyclic reflective model influence students' creativity in instructional designing. The designing here refers to lesson objectives and success indicators formulation, decision of teaching strategies used to achieve the lesson objectives, and the choice of teaching media for effective teaching and learning procedures.

\section{RESEARCH METHOD}

This classroom research employed a mixed qualitativequantitative design in which qualitative data sets were collected from observation, cyclic reflective journal, and interview. The quantitative data were collected through teachers' creativity questionnaire developed from Sternberg's five component of creativity as mentioned above. venturesome personality, intrinsic motivation, and creative environment. The subjects were 60 prospective English teachers who were undertaking first degree program in English Education. Specifically, they were sitting in the Strategy and Design Course which were allocated for 16 regular in class activities of 150 minutes each, and the same amount of time for dependent learning. The 60 students were divided into two groups, the first was the experimental group treated with cyclic reflective model (hereafter, CRM), in which feedbacks mostly came from the students' self-evaluation of their own work; while the other group was treated with the regular method in which feedbacks came from outside the students (i.e. from trainers and peers or classmates). The first group was also provided with self-rated creativity checklist to assure that their designs reflect their creativity as a teacher to be. All data were triangulated and were analyzed descriptively.

\section{RESULTS AND DISCUSSION}

The two groups involved in the study went through the same activities. They all had to work on a different project in every three weeks. Thus in 16 regular classes, they had four instructional designing projects, the first and the third were group projects that respectively for junior high school and senior high school students. The second and the forth ones were individual projects that were also for junior and senior high schools. Finally, at the end of the semester, all students should submit one individual project for product assessment. The only difference between Experimental and Control groups was that the first was given a CRM questions that they have to answer honestly, while the second group went through an 'ordinary' class in which students got feedback from the instructors and their peers.

Based on the observation, all students from both groups were engaged actively in planning the lessons, exploring relevant learning resources and making decisions on what and how to use to make the lessons effective and what teaching media needed for achieving the lesson objectives. The followings are the results of the Teaching Creativity Questionnaire (hereafter, TCQ) with particular highlight of the differences between the experimental and the control groups.

TABLE I. EXPERIMENTAL AND CONTROL GROUPS'RESPOND TO TCQ

\begin{tabular}{|l|l|l|}
\hline Creativity component & \multicolumn{1}{|c|}{ Experimental group } & \multicolumn{1}{|c|}{ Control Group } \\
\hline Expertise & $\begin{array}{l}\text { Showing concern on operational verbs used for lesson objective and } \\
\text { success indicators' reformulation, use of interesting visual and audio- } \\
\text { visual images }\end{array}$ & $\begin{array}{l}\text { Showing concern on operational verbs used for lesson objective and } \\
\text { success indicators' reformulation, use of interesting visual and audio-visual } \\
\text { images }\end{array}$ \\
\hline $\begin{array}{l}\text { Imaginative thinking } \\
\text { skills }\end{array}$ & $\begin{array}{l}\text { Showing efforts to adapt commonly used strategies, creating new } \\
\text { strategies to make the lessons more fun }\end{array}$ & Showing effort to find relevant strategies, either to adopt or to adapt them. \\
\hline $\begin{array}{l}\text { A venturesome } \\
\text { personality }\end{array}$ & $\begin{array}{l}\text { Showing efforts to create new design of tasks including the procedures, } \\
\text { willing to take risks for possible time extension }\end{array}$ & $\begin{array}{l}\text { Showing effort to try new design, follow the readily available procedures } \\
\text { and willing to take risks for unexpected consequences }\end{array}$ \\
\hline Intrinsic motivation & $\begin{array}{l}\text { Showing motivation for self- satisfaction, being reflective and evaluative } \\
\text { toward the projects and willing to do revision }\end{array}$ & $\begin{array}{l}\text { Showing motivation to produce good project that deserve compliments } \\
\text { from the instructors, willing to revise based on the feedback given. }\end{array}$ \\
\hline Creative environment & Showing effort for voluntarily consultation to instructors and get supports & Showing efforts to get supports from the instructors. \\
\hline
\end{tabular}


As revealed in Table 1, differences between the two groups were obvious in the components of imaginative thinking skills in which students in the experimental group did not only use a strategy in a different way but seemed to be more challenged to adapt / modify existing methods or create new strategies. The examples of modification made were: Jigsaw Reading into Count-Circle Jigsaw Reading and Role Play was modified into Nirama or Mini Drama). The control group was not found to make this kind of modification. Similarly, in a venturesome personality, the experimental group tend to create more names for strategy used, such as news production strategy and news broadcasting strategy for teaching the topic of News Item. They also produced Hoking \& Homing (shortened from hortatory making and performing) for teaching hortatory texts. In addition, there were many modifications and creation, such as snake chained ladder game, story-telling competition, motivation cards, character paper, scientific text creation, etc. These indicate developing imaginative thinking skills. While modifying or creating a strategy, they could imagine the procedures and class situation as the results of the implementation of the strategies.

Intrinsic motivation can be detected from enthusiasm and motivation to produce innovative, inspiring, challenging and fun lessons as mandated by the ministerial regulation No 22, year 2016 In addition to what came up during the class discussion, the first group refer to their own cyclic reflective strategy in making revision toward their project. The second group, however, most of the time refer to the feedback given by the instructors and peers. It is then not difficult to imagine that the first group had more dynamic process in their instructional designing since they dynamically ask and answer questions about their project and make revision accordingly.

Both groups indicate willingness to revise their instructional design, however, students in the second group were more likely to rely on the feedbacks from the outsider (the instructors and the peers), while the first group also refer to their own reflection guided by the CRM questions and the selfrated creativity checklist. The followings are the findings from the creativity checklist.

TABLE II. STUDENTS' SELF-RATED CREATIVITY SCORES

\begin{tabular}{|l|l|l|l|}
\hline No & \multicolumn{1}{|c|}{ Creativity components } & $\begin{array}{c}\text { E.G. average } \\
\text { score }\end{array}$ & $\begin{array}{c}\text { C.G. Average } \\
\text { score }\end{array}$ \\
\hline 1 & Expertise & 3.16 & 2.97 \\
\hline 2 & Imaginative thinking skills & 3.06 & 2.88 \\
\hline 3 & A venturesome personality & 3.47 & 2.86 \\
\hline 4 & Intrinsic motivation & 3.27 & 3.16 \\
\hline 5 & Creative environment & 3.37 & 3.27 \\
\hline
\end{tabular}

E.G. = Experimental Group (First Group) C.G. $=$ Control Group (Second Group)

Consistent differences in the five components of creativity between E.G. and C.G. were found. As revealed in Table 2 E.G. exceed the average scores of C.G. in all the five components. From the interview data, it was found that the first group were more concerned about new things (i.e. new strategies, new materials, new teaching media, new teaching procedures) to meet their need for effective teaching. The data indicate that students treated with CRM were more aware of the need to be creative and were more likely to be able in which E.G. showed more confidence about their ability to design creative instructional design.

Significant difference was found in the component of adventuresome skills indicating that students treated with cyclic reflective model were consistently 'empowered' to be analytical and critical about their own design and were more willing to try and create new ways / strategies and were more confident in making decision for overcoming problems / obstacles. The questions such as "what is good and bad about your design?" seem to be powerful, as indicated by the results of the interview. In answering this question, they have to be critical about the strengths and weaknesses of their design, and this was not enough. The questions resulted in extended analysis about why it was weak and what need to be done to improve it.

Slight differences in the components of expertise and intrinsic motivation is an indication that both groups were well informed about the concepts and principles of instructional designing and both were aware of the importance to demonstrate knowledge and skills in the design. The slightly higher scores of the E.G. in these components may be due to a better developed critical thinking skills as the results of the employment of cyclic reflective model that make students more sensitive in making decision.

The use of Cyclic Reflective Model is likely to be influential towards students' imaginative thinking skills. This is indicated by the higher score of E.G. in this component. They seemed to have better ability to foresee the class atmosphere while developing their designs and are able to predict what will work well and how it will work when it is implemented in the classroom. These findings are confirmed by the results of the interview. Many students from Group 1 mentioned about the need to foresee the class when they were planning for a lesson. As the results, they have to be able to think systematically about what to do step by step. The ability to foresee what is going to happen in the classroom make them more creative as well as more anticipative towards teaching obstacles. Students in the second groups also show effort to be creative, however, the creativity was more limited to the use of various strategies readily available in various learning resources so that there is a tendency that this may not anticipative to possible obstacles in the real teaching.

\section{CONCLUSION}

This research can be considered as preliminary to a bigger research that uncover the problems of creativity on the part of the teacher in Indonesian schools. The findings of this research may be treated as the stepping stone for in service professional development programs for teachers in the future. Being reflective towards own lesson planning and instructional process is very important because the results will meet perfectly with personal strategies to overcome the problems. So far, many of the professional development programs for teachers are anticipative in nature, in which problems were assumed to be encountered by most teachers and the solutions to those tend to be more general. Cyclic reflective model allows teachers to foresee real problems and solve them subjectively. The ability to identify and solve the problems 
[9] H. Penn, Understanding Early Childhood. Issues and Controversies. New York: Open University Press, 2005.

need creativity. Therefore, there is a 'chicken-egg' relationship between self-reflection and creativity. One need to be creative to solve problems, and creativity lead someone to identify what the problems are.

\section{ACKNOWLEDGMENT}

The authors would like to express their high appreciation to Class $4 \mathrm{~B}$ and $4 \mathrm{E}$ for their cooperation and supports for the whole semester so that the data collection procedure could run effectively. High appreciation is also forwarded to the Ministry of Research, Technology, and Higher Education for the financial support through the research center of Ganesha University of Education Bali.

\section{REFERENCES}

[1] Gammo J. Cultivating Honorable Character. USA: Kesaint Blanc Publishing, 2012.

[2] S. Kammarudin, "Character Education and Students Social Behavior," J Educ Learn, vo.1 6, no. 4, pp. 223-30, 2012.

[3] P. Nilan, "Teachers' Work and Schooling in Bali,", Int Rev Educ., vol. 9, no. 6, pp. 563-84, 2003.

[4] Y.E. Harususilo, "Siswa Indonesia Raih Prestasi di Olimpiade Fisika Dunia Israel," Kompas.com [Online]. Retrieved from: https://edukasi.kompas.com/read/2019/07/15/07423241/siswaindonesia-raih-prestasi-di-olimpiade-fisika-dunia-israel?page $=$ all, Accessed, 2019 Jul 15.

[5] L.P. Artini, "Integrating universal and local values in character education in Indonesian schools," In: The Third International Conference on English across. Singaraja: Undiksha, 2016.

[6] V. Battistich, "Character Education, Prevention, and Positive Youth Development," [Online], Retrieved from: www.character.org/wpcontent/uploads/2011/12/White_Paper_Battistich.pdf, 2012 [cited 1BC Aug 20].

[7] D. Shields, "Character as the Aim of Education," kappanmagazine.org [Online], Retrieved from: pdk.sagepub.com, Accessed, 2011, (May), pp. $48-53$.

[8] K. Matsuba and L. Walker, "Extraordinary moral commitment: Young adults working for social organizations," J Pers., vol. 72, pp. 413-36, 2004
[10] P. Vihar, "Life Skills Education \& CCE," [Online]. Central Board of Secondary Education. 2019. Retrieved from: http://www.cbse.nic.in/cce/life_skills_cce.pdf

[11] B. Kesuma, "School Activities to Develop 21st Century Skills," [Online]. British Council. 2014. Retrieved from: https://www.britishcouncil.vn/sites/default/files/7.2_workshop_global_ci tizens_-barlin_kesuma_idn_en.pdf

[12] S.A. Hartzell and M.T. Greene, "Fostering Creativity in the Classroom : Effects of Teachers' Epistemological beliefs, Motivation, and Goal Orientation,” J Creat Behav., vol. 43, no. 3, pp. 192-208, 2009.

[13] M.S. Knowles, Self-Directed Learning. Prentice Hall: Cambridge Adult Education, 1975.

[14] R. Moog, S. James, C. Frank, T. Wolfskill, D. Hanson and A Stroumanis, "Process oriented guided inquiry learning," [Online]. Project Kaleidoscope. 2019. Retrieved from: https://serc.carleton.edu/sp/pkal/pogil/index.html

[15] Kazempour, "The Effects Of Inquiry- Based Teaching On Critical Thinking Of Students," J Soc Issues Humanit., vol. 1, pp. 23-7, 2013.

[16] L. Stoller, "Project work: A means to promote language and content," English Teach Forum, vol. 35, no. 4, pp. 2-9, 1997.

[17] A. Patton, Work that matters: The teacher's guide to project-based learning. London: The Paul Hamlyn Foundation, 2012.

[18] S. Haines, Projects :for the EFL Classroom: resource material for teachers. Walton-on-Thames: Nelson, 1989.

[19] T. Markham, Project based learning handbook: A guide to standardsfocused project based learning for middle and high school teachers. Novato CA: Buck Institute for Education, 2003.

[20] I. Fragoulis, "Project-Based Learning in the Teaching of English as A Foreign Language in Greek Primary Schools : From Theory to Practice," English Lang Teach., vol. 2, no. 3, pp. 113-9, 2009.

[21] S. Bell, "Project-Based Learning for the 21st Century: Skills for," Clear House, vol. 83, no. 2, pp. 39-43, 2010.

[22] J. Hackathorn, E.D. Solomon, K.L. Blankmeyer, R. Tennial and A. Garczynski, "Learning by Doing: An Empirical Study of Active Teaching Techniques," J Eff Teach., vol. 11, no. 2, pp. 40-54, 2011.

[23] L. Qing-xue and S. Jin-fang, "An Analysis of Language Teaching Approaches and Methods: Effectiveness and Weakness, "US-China Educ Rev. vol. 4, no. 1, pp. 69-71, 2007.

[24] L.P. Artini, Learning English in Bali: Investigating beliefs and language learning srategies. Newcastle University, 2006. 